умінь і навичок в практичній реалізації складових військової компоненти. Для реалізації поставленої мети використано комплекс таких методів: теоретичні методи аналізу, синтезу, обгрунтування, узагальнення, систематизації теоретичного i практичного матеріалу дослідження. Посилення практичної підготовки курсантів, а саме впровадження тренінгів для курсантів випускного курсу здійснюється на таких кафедрах: тактики прикордонної служби; прикордонного контролю; загальновійськових дисциплін; особистої безпеки; конституційного, адміністративного та міжнародного права; інженерного забезпечення та технічних засобів охорони кордону. Із впровадженням тренінгів, з відпрацювання способів практичних дій (із загальновійськової, військово-інженерної, вогневої та медичної підготовки, прикордонного контролю, тактики прикордонної служби, особистої безпеки, адмінпровадження) отримано вдосконалення практичних навичок у курсантів випускних курсів і підвищення практичної компоненти професійної підготовки.

Ключові слова: посилення практичної підготовки, тренінги, майбутні офіцери-прикордонники, Україна.

Submitted on March, 6, 2017

UDC: $378.147:[373.5 .011 .3-051: 80]$

DOI: https://doi.org/10.24195/2414-4665-2017-4-2

Nataliia Siaska,

PhD (Candidate of Pedagogical Sciences), associate professor, Department of Foreign Language Teaching Methodology, Rivne State Humanitarian University, 31, Plastova Str., Rivne, Ukraine

\title{
POETRY AS A MEANS OF DEVELOPING FUTURE TEACHERS-PHILOLOGISTS' SPEAKING SKILLS
}

Nowadays teaching foreign languages to students is aimed at their mastering of intercultural communication in standard situations on the basis of communicative minimum including certain knowledge of linguistic and cultural studies. Proper attention should be paid to the selection of teaching material: it must be authentic, in our case - authentic poetry. The paper aims to describe the ways of improving students' practical readiness for oral communication, elicit potential of poetic texts and consider them as a means of enriching students'vocabulary based on reading and analysis. It will allow future foreign language teachers to improve their proficiency, prepare themselves for tolerant attitude towards other cultures and nations as well as comparing them with the specific character of their own culture, critical reflection of it and the system of personal values. Advancement of teaching English vocabulary is implemented through interactive teaching reading and understanding authentic poetry through the system of individual tasks. The latter are aimed at stimulation of reading authentic poetry by students, development of their abilities and skills of independent work on these tasks, raising the level of mastering foreign language vocabulary. Work with poetry may be used efficiently for the development of students' creative thinking as motivation for enrichment vocabulary with culturespecific words and for the development of spontaneous speech.

Keywords: intercultural communication, innovative method, authentic foreign language communication.

\section{Introduction}

In today's society, there is a challenging problem of training skilled personnel for every sphere of activity, including higher linguistic educational institutions. State documents on higher education place emphasis on the necessity to educate the new generation of teaching staff prepared for meeting educational needs of every personality, development of his/her intellectual and cultural potential. In this context, improvement of the efficiency of training future teachers of foreign languages becomes a topical issue of contemporary higher pedagogical education. Nowadays teaching foreign languages to students is aimed at their mastering of intercultural communication in standard situations on the basis of communicative minimum including certain knowledge of linguistic and cultural studies.
Besides, future philologists should be able to teach foreign literature and country studies [5]. The main purpose of teaching foreign languages to students of linguistic specialties is the formation of their communicative competence. The main strategic orientation of the English Curriculum for students of higher educational institutions is the formation of professional communicative competence.

With regard to the above-mentioned purposes, proper attention should be paid to the selection of teaching material: it must be authentic; in our case, it is reasonable to use authentic poetry. Authentic texts are those that are used in everyday life of native speakers, their real output, which is characterised by inartificial vocabulary, grammatical forms, usage of contextually appropriate means of a language [1].

In the works on teaching methods, poetic texts are 
considered as a means of teaching foreign languages. For example, work with English and French poetic texts at secondary school was studied by $\mathrm{H}$. Podosynnikova and N. Tsurtsylina correspondingly; teaching reading and English discussions based on poetry were considered by T. Kamaieva and N. Andronik; the principles of using poetry as a means of forming intercultural competence and activation of students' learning and cognitive activity (I. Lukianchenko). Saraç also explains the educational benefits of poetry as follows: it provides readers with a different view point towards language use by going beyond the known usages and rules of grammar, syntax and vocabulary; triggers unmotivated readers owing to being so open to explorations and different interpretations; evokes feelings and thoughts in heart and in mind, makes students familiar with figures of speech (i.e. simile, metaphor, irony, personification, imagery, etc.) due to their being a part of daily language use.

However, a great number of research works do not cover all the aspects of teaching foreign languages. For example, none of the works reviewed the opportunities of forming foreign language communicative competence on the basis of poetry as an important part of national culture and aesthetic values of native speakers. Also, educative and aesthetic potential of poetic texts were not considered by the above-mentioned authors. Therefore, the paper aims to describe the ways of improving students' practical readiness for speaking, elicit potential of poetic texts and consider them as a means of enriching students' vocabulary based on reading and analysis. The task of the paper is to prove that rhymed representation of material improves the efficiency of teaching foreign languages.

\section{Discussion}

Dealing with this task in the current context requires a teacher's thorough understanding of personality-oriented educational paradigm, creative approach to the organisation of foreign languages teaching. Proper attention should be paid to the selection of socio-cultural learning material, including poetry, as a means of students' communicative competency. In this regard, it is reasonable to use authentic learning material in order to make students' speaking skills authentic as well. The use of poetic texts in teaching foreign languages at linguistic universities will improve the efficiency of forming students' practical readiness for foreignlanguage authentic communication. It will allow future foreign languages teachers to improve their proficiency, prepare themselves for tolerant attitude towards other cultures and nations as well as comparing them with the specific character of their own culture, critical reflection of it and the system of personal values.

With regard to the above-mentioned, the essence of the concept of future teachers-philologists' speaking skills that are formed on the basis of poetic texts is the unity of practical and theoretical components. The practical component includes command of the language of English poetic texts, word-formation means, lexical norms of its use; abilities and skills of using poetic vocabulary in learning and real life communication in English; the abil- ity to analyse lexical component of one's own speech and improve it. The theoretical component includes professional philological knowledge of poetic terms, literary terms, lexicological categories; linguistic, historical and content analysis of a text; poetic presentation of thoughts on the subject that is being learned.

Considering the need for improving the quality of training foreign language teachers in the system of higher education, authentic poetry is an effective means of forming communicative competence at foreign language classes with senior students.

For improving students' speaking skills by means of poetry, we have chosen the following aspects of foreign language teaching: the influence of poetry on the development of background speech culture, which involves knowledge of English vocabulary with national cultural semantics as well as words denoting culture-specific features of daily life, customs, the ability to use lexical units conveying socio-cultural information, symbols, realia, artifacts, clichés, grammar expressive means with sociocultural features in the process of intercultural communication in English. This aspect is implemented by means of partial introduction of additional background knowledge and corresponding linguistic means that are consistent with the textbook material in terms of content, complexity level and the level of students' proficiency into foreign language classes.

The formation of lexical abilities and skills in senior students (future foreign language teachers) involves systematisation of the acquired lexical units, including the ones denoting cultural realia, the ability to use them appropriately and recognise culture-specific vocabulary. Advancement of teaching English vocabulary is implemented through interactive teaching reading and understanding authentic poetry through the system of individual tasks. The latter are aimed at stimulation of students' reading authentic poetry, development of their abilities and skills of independent work on these tasks, raising the level of mastering foreign language vocabulary. These strategies should be implemented when studying every new topic.

At practical English lessons poetry creates favourable conditions for the development of creative thinking: the deeper is students' aesthetic knowledge, the better imagination and thinking they have, thus they will be willing to express and substantiate their points of view. Work with poetry may be used efficiently for the development of students' creative thinking as motivation for enrichment vocabulary with culture-specific words and for the development of spontaneous speech. Linguistic material of poetry (particularly lexical units) is represented in its natural contextual environment; consequently, it is easily memorised and recognised while reading and listening, used in speaking and writing. The influence of poetry on the development of students' creative thinking is targeted at their independent search for new information and methods of work, solving educational problems. Therefore, it contributes to the formation of a certain mindset, invincible beliefs, comprehensive acquisition of knowledge and the 
ability to use it creatively. On the other hand, this aspect facilitates the formation of success achievement motivation, the development of students' intelligence. As can be seen from the above, implementation of this aspect involves the formation and development of students' creativity by means of activating their thinking taking into account poetry-based problem situations created by the teacher in the process of students' acquisition of new lexical knowledge, abilities and skills.

The development of future teachers-philologists' speaking skills is impossible without mastering general cultural rules of behaviour and stylistic culture of speech associated with knowledge of poetic acronyms, unusual word forms, violation of typical rules of logical ordering and positions of words in word combinations and sentences; the abilities to arrange culturally specific linguistic and speech material in the process of intercultural interaction in English; the abilities to choose appropriate style of speech and form of an utterance depending on the purpose of communication, express thoughts, intents and feelings independently using the vocabulary learned before, interpret native speakers' responses to students' speaking.

This aspect may be implemented in the following forms: self-directed learning under teacher's supervision; autonomous learning in a foreign language in private or in a group using diverse authentic poetry (under teacher's supervision); self-directed mastering of the foreign language with the help of a learning guide without teacher's assistance; one-to-one teaching with one or several teachers; self-directed learning of the foreign language at selfaccess centres.

\section{REFERENCES}

1. Andronik, N. P. (2009). Navchannia maibutnikh uchyteliv anglomovnoi dyskusii na osnovi avtentychnykh poetychnykh tvoriv [Teaching English discussion to future teachers based on authentic poetry]. Extended abstract of candidate's thesis. Kyiv [in Ukrainian].

2. Yeremenko, T. Ye., \& Podliesna, A. V. (2009). Interaktyvni metody $\mathrm{u}$ vykladanni spetskursiv ta spetsseminariv na fakulteti inozemnykh mov [Interactive methods in teaching special courses and special seminars at Foreign Languages Department]. Vykorystannia interaktyvnykh metodiv pry vykladanni movy ta literatury $u$ serednikh ta vyshchykh navchalnykh zakladakh - Using interactive methods in teaching language and literature in secondary and higher education: Proceedings of the Fourth Interuniversity Research and Practice Conference (Vols. 2). (pp. 3-11). Yalta: RVV KGU [in Ukrainian].

3. Kamaeva, T. P., Karpova, L. V., Deeva, I. M. (1996). Poeziia na uroke inostrannogo iazyka : sovremennye podkhody k obucheniiu chteniiu [Poetry at foreign language lessons: modern approaches to teaching reading]. Inostrannye iazyki $v$ shkole - Foreign languages at school, 3, 19-28 [in Russian].

4. Lukianchenko, I. O. (2014). Poeziia yak zasib aktyvizatsii navchalno-piznavalnoi diialnosti studentiv
One more effective aspect of improving students' speaking skills by means of poetry is solving creative problems by students. To prepare students-philologists for authentic communication in English using poetry, it is necessary to form lexical knowledge, abilities and skills: knowledge of phraseological units, colourful expressions and the ability to use culture-specific linguistic units in the process of a communicative act in English, choose appropriate linguistic forms and ways of their expression depending on the character of a speech act. It is reasonable to organise roundtable discussions on certain topics with the purpose of effective formation of communicative competence at English lessons.

Working at higher linguistic educational institutions, the teacher should set the central task for students: the development of general cultural abilities to collect, systemise and generalise culture-specific and other information, which is interesting for students. They should be able to use the foreign language to introduce a country, its culture, image and people's lifestyle. By referring to poetry the teacher strengthens and develops relations of the English language with other subjects, primarily with English Literature, Lexicology, Translation Theory and Practice, Stylistics, History of the English Language, English Derivational Morphology.

\section{Conclusions}

Inclusion of poetry into the process of teaching foreign languages at linguistic universities will improve the efficiency of training future teachers. Learning poetry at foreign language classes will make it possible to fulfill educational tasks and raise the level of future specialists' authentic communication skills.

fakultetiv inozemnykh mov na zaniattyakh z kursu "Praktyka usnoho ta pysemnoho movlennia" [Poetry as a means of enhancing students' learning at the classes of Practical English Course]. Suchasna nauka: teoriya i praktyka - Contemporary science: theory and practice: Proceedings of the Fourth Interuniversity Research and Practice Conference (pp. 75-77). Kyiv: Partnerstvo "Nova Osvita" [in Ukrainian].

5. Holovach, Yu. V., Nikolaieva, S. Yu., \& Solovei, M. I. (2001). Prohrama $z$ anhliiskoi movy dlia universytetiv / instytutiv (piatyrichnyi kurs navchannia) [English Curriculum for universities / institutes (practical course)]. Kyiv: Kyivskyi derzhavnyi linhvistychnyi universytet [in Ukrainian].

6. Podosynnikova, H. I. (2001). Eksperymentalna perevirka efektyvnosti kompleksu vprav z navchannia idiomatychnykh predykatyvnykh konstruktsii anhliiskoho rozmovnoho movlennia [Experimental verification of the effectiveness of exercise training complex to teach English idiomatic predicate constructions of conversational speech]. Visnyk Kyivskoho derzhavnoho linhvistychnoho universytetu. Seria "Pedagogika i psykholohia" - Bulletin of Kiev State Linguistic University, 4, 75-82. Kyiv: Kyivskyi derzhavnyi lingvistychnyi universytet [in Ukrainian] 
7. Saraç, S. (2003). A Suggested Syllabus for the Teaching of Poetry Course in ELT Departments of Turkey.

\section{ЛІТЕРАТУРА}

1. Андронік Н. П. Навчання майбутніх учителів англомовної дискусії на основі автентичних поетичних творів : автореф. дис.... канд. пед. наук : 13.00.02. / Н. П. Андронік. - К., 2009. - 22 с.

2. Єременко Т. Є. Інтерактивні методи у викладанні спецкурсів та спецсемінарів на факультеті іноземних мов : матеріали 4-ої міжвуз. наук.-практ. конф. [“Використання інтерактивних методів при викладанні мови та літератури у середніх та вищих навчальних закладах"], (27 листопада 2009 р.) / Т. Є. Єременко, А. В. Подлєсна. - Ялта : РВВ КГУ, 2009. - Ч. 2. - С. 3-11.

3. Камаева Т. П. Поэзия на уроке иностранного языка : современные подходы к обучению чтению / Т. П. Камаева, Л. В. Карпова, И. М. Деева // Иностранные языки в школе. - 1996. - № 3. - С. 19-28.

4. Лук'янченко I. О. Поезія як засіб активізації навчально-пізнавальної діяльності студентів факультетів іноземних мов на заняттях 3 курсу «Практика усного та писемного мовлення» / I. О. Лук'янченко // Сучасна наука: теорія і практика: матеріали Всеукра-
Unpublished M.A. thesis. Ankara: Hacettepe University.

їнської науково-практичної заочної конференції «Сучасна наука: теорія і практика» (м. Київ) / Партнерство «Нова Освіта». - К., 2014. - С. 75-77.

5. Програма з англійської мови для університетів / інститутів (п’ятирічний курс навчання): Проект / Колектив авт. : Ю. В. Головач, С. Ю. Ніколаєва, M. I. Соловей та ін. - К. : Київський державний лінгвістичний університет, 2001. - 245 с.

6. Подосиннікова Г. І. Експериментальна перевірка ефективності комплексу вправ 3 навчання ідіоматичних предикативних конструкцій англійського розмовного мовлення / Г. І. Подосиннікова // Вісник Київського державного лінгвістичного університету. Серія «Педагогіка та психологія». - К. : Вид. центр Київського держ. лінгв. ун-ту, 2001. - Вип. 4. - С. 75-82.

7. Saraç S. A suggested syllabus for the teaching of poetry course in ELT Departments of Turkey / S. Saraç // Unpublished M.A Thesis. - Ankara : Hacettepe University, 2003.

Наталія Володимирівна Сяська, кандидат педагогічних наук, доцент кафедри методики викладання іноземних мов, Рівненський державний гуманітарний університет, вул. Пластова, 31, м. Рівне, Украӥна

\section{ПОЕТИЧНІ ТВОРИ ЯК ЗАСІБ УДОСКОНАЛЕННЯ МОВЛЕННСВОЇ ДІЯЛЬНОСТІ МАЙБУТНІХ УЧИТЕЛІВ-ФІЛОЛОГІВ}

Сучасне навчання студентів іноземної мови передбачає їх спілкування на міжкультурному рівні в найбільш типових ситуаціях на основі комунікативного мінімуму, який повинен включати певний обсяг країнознавчих та лінгвокраїнознавчих знань. У цьому разі доречним є дотримання автентичності навчальних матеріалів, а саме - використанням автентичного поетичного матеріалу. Метою статті є пошук шляхів підвищення практичної готовності студентів до мовленнєвої діяльності, виявлення потенціалу поетичних текстів та розгляд їх як засобу збагачення словникового запасу студентів на основі читання та аналізу. Використання автентичних поетичних текстів допоможе майбутнім учителям іноземних мов опанувати фаховими знаннями, підвищити професійну майстерність, підготувати особистість не лише до толерантного сприйняття інших культур та народів, а й до порівняння їх 3 власною соціокультурною специфікою, до критичної рефлексії стосовно неї і до системи особистісних цінностей. Мовленнєва діяльність майбутніх учителів-філологів, що формується на основі поетичних текстів, представляє єдність двох складових: практичної і теоретичної. Практична складова включає знання мови англомовних художніх поетичних творів, навички та вміння практичного використання лексики поетичних творів в умовах навчальної та реальної англомовної комунікації та ін. Теоретична складова включає знання поетичних термінів, літературознавчих понять, лексикологічних категорій; вміння використання теоретичних знань у процесі аналізу художніх поетичних текстів і т. ін. Реалізація вдосконалення навчання англомовної лексики передбачає інтерактивне навчання читання і розуміння автентичних поетичних творів через систему індивідуальних вправ. Метою таких індивідуальних завдань $є$ стимулювання студентів читати автентичні твори, розвивати навички та вміння самостійної індивідуальної роботи над ними, підвищувати рівень опанування лексичним аспектом іноземної мови. Вважаємо за можливе використовувати потенціал роботи з римованими творами для розвитку творчого мислення студентів як стимул для збагачення словникового запасу безеквівалентною лексикою та розвитку непідготовленого мовлення.

Ключові слова: міжкультурна комунікація, інноваційний метод, автентичне іншомовне спілкування.

Submitted on March, 10, 2017

Reviewed by Doctor of Pedagogy, prof. O. Bezkorovaina 